BOUBACAR Sidi Diallo

Uniwersytet im. Adama Mickiewicza

w Poznaniu

\title{
THE RIGHT TO INCLUSIVE EDUCATION IN THE LIGHT OF THE CONVENTION ON THE RIGHTS OF PERSONS WITH DISABILITIES
}

\begin{abstract}
AвSTRACt. Sidi Diallo Boubacar, The Right to Inclusive Education in the Light of the Convention on the Rights of Persons with Disabilities [Prawo do równego traktowania w edukacji w świetle Konwencji o prawach osób niepełnosprawnych]. Studia Edukacyjne nr 47, 2018, Poznań 2018, pp. 329-342. Adam Mickiewicz University Press. ISSN 1233-6688. DOI: 10.14746/se.2018.47.20

This article examines the rights of persons with disabilities in the field of inclusive education based on fundamental human rights outlined in the Convention on the Rights of Persons with Disabilities. Inclusive education is essential to achieve universal respect for the right to education, including persons with disabilities. Only inclusive education systems can offer persons with disabilities both quality education and the opportunity to improve their social situation. Inclusive education is not just about placing students with disabilities in mainstream educational institutions; it also means making them feel welcome, respected and valued. The values that underlie the concept of inclusive education reinforce the capacity of everyone to achieve their goals and to conceive of diversity as a source of enrichment. Students with disabilities need appropriate support to participate in the education system on an equal basis with other students. Ordinary educational institutions must provide students with disabilities with a learning environment that maximizes academic progress and socialization.
\end{abstract}

Key words: convention, law, education, inclusion, disability, human rights

\section{Introduction}

The right to education is a universal right recognized by international human rights law and, as such, applies to everyone, including persons with disabilities. Several international instruments, such as the Universal Declaration of Human Rights, the International Covenant on Economic, Social and Cultural Rights and the Convention on the Rights of the Child, embody the fundamental principles of universality and non-discrimination in the exercise 
of the right to education. ${ }^{1}$ Inclusive education has been recognized as the most appropriate way for states to guarantee these two fundamental principles. The Convention on the Rights of Persons with Disabilities recognizes that for these rights to be exercised, inclusive education systems must be in place and, therefore, the right to education includes the right to inclusive education.

Generally, school systems have adopted one of three strategies for persons with disabilities: exclusion, segregation or inclusion. Exclusion occurs when a pupil is kept away from school on the basis of the existence of a disability, without there being other educational alternatives on equal terms with other pupils on the basis of age, development or diagnosis established, the student is placed in a social or medical institution without access to education. There is segregation when this student is sent to a school so that his particular disability is taken care of, lye more often in a school or specialized educational system. Finally, there is integration when a disabled student is enrolled in an ordinary $^{2}$ school, provided that he or she can adapt to the standardized provisions of the school. The integration strategy is only intended to increase the student's ability to meet established standards. ${ }^{3}$

\section{Inclusion as a fundamental principle of education}

Inclusion is a process that recognizes: On the one hand the obligation to remove barriers that limit or prohibit the participation of persons with disabilities; and the need to change the culture, direction, and practice ${ }^{4}$ of mainstream schools to reflect the needs of all students, especially those with disabilities. Inclusive education involves transforming the education system and ensuring interpersonal interactions based on core values that allow for the full development of one's learning abilities. It also assumes effective participation, individualized instruction, and inclusive pedagogies. Some of the core values of inclusive education are equality, participation, non-discrimination, celebration of diversity and sharing of good practices. The inclusive approach sees students as people, respects their own dignity and recognizes their

${ }^{1}$ See the final observations du Comite des droits des personnes handicapées concernant l'Argentine, CRPD/C/ARG/CO/1, et l'Espagne, CRPD/C/ESP/CO/1.

${ }^{2}$ Les expressions «écoles ordinaires» et «éducation générale» sont habituellement utilisées pour faire référence à des systèmes scolaires où sont scolarisés des élèves handicapés ou non, par opposition aux écoles spécialisées, où ne sont scolarisés que des élèves handicapés. Dans le présent rapport, les premières expressions sont interchangeables pour renvoyer à l'éducation générale, étant donné qu'il est fait mention de ces écoles dans la Convention relative aux personnes handicapées.

${ }^{3}$ See UNICEF, The Right of Children with Disabilities to Education: A Right-Based Approach to Inclusive Education (Genève, 2012).

${ }^{4}$ See: T. Booth M. Ainscow, The Index for Inclusion: Developing Learning and Participation in Schools, Bristol 2004. 
needs and their ability to contribute to society. It also recognizes difference as a chance for learning and sees the relationship between school and wider community as a way to create inclusive societies with a sense of belonging (not only for students but also for teachers and parents).

Inclusive education is socially important because it provides a forum for fighting against stigma and discrimination. A blended learning framework that includes people with disabilities helps to value their contributions and to challenge and gradually eliminate prejudices and misunderstandings. Inclusive education also enhances quality education for all by leading to broader programs and teaching strategies that contribute to the overall development of skills and competencies. This correlation between learning and development, when it encompasses diverse participants with diverse skills, opens up new opportunities for achieving goals and self-esteem, and empowers individuals to build a society based on mutual respect and rights. The realization of the right to education is a prerequisite for social and economic inclusion and full participation in society. The right to education has therefore been recognized as an example of the indivisibility and interdependence of all human rights, given its role in the full and effective realization of other rights. ${ }^{5}$ Formal education facilitates formal certification, which is now required more and more often in the open labor market. Thus, it is necessary for people with disabilities to obtain diplomas and educational certificates under the same conditions as others in order to compete with them and be part of the workforce. This is all the more important as the unemployment rate of persons with disabilities is proportionally higher because of discrimination. ${ }^{6}$ In addition, the increased employability of people with disabilities reduces costs and contributes to economic growth. The negative impact of the unemployment of the disabled on the gross ${ }^{7}$ domestic product could be reduced by guaranteeing these people access to inclusive education systems.

\section{Normative evolution of the right to inclusive education}

Recognized as a fundamental right in Article 26 of the Universal Declaration of Human Rights, the right to education was subsequently enshrined in various legal instruments that broadened its scope and specified the obliga-

${ }^{5}$ See le Comité des droits économiques, sociaux et culturels, Observations générales no 11 (1999) sur les plans d'action pour l'éducation primaire et $n^{\circ} 13$ (1999) sur le droit à l'éducation.

${ }^{6}$ Pour de plus amples détails à ce sujet, voir l'étude thématique du HCDH sur le travail et l'emploi des personnes handicapées (A/HRC/22/25).

${ }^{7}$ S. Buckup, The price of exclusion: The economic consequences of excluding people with disabilities from the world of work, Employment Working Paper, 2009, n 43, OIT. 
tions of States. This process eventually led to the recognition in the Convention on the Rights of Persons with Disabilities that inclusive education is the best way to guarantee this right to all. ${ }^{8}$ The Convention against Discrimination in Education, the International Convention on the Elimination of All Forms of Racial Discrimination and the International Covenant on Economic, Social and Cultural Rights have all led forward in this direction. In accordance with article 13 of the International Covenant on Economic, Social and Cultural Rights, the right to education includes: free and compulsory primary education for all; secondary education, including technical and vocational education, and generalized higher education, made accessible to all, in full equality, by gradual introduction of free education; encouragement of basic education for adults who have not received primary education or who have not received it to completion; and the development of a school network, the establishment of a scholarship system and programs for the continuous improvement of the working conditions of teachers. The Covenant further recognizes the right of parents or guardians to choose the type of education to be provided to their children, provided that it conforms to the minimum standards of education.

While providing for the progressive realization of the rights it devotes and taking into account the constraints due to the limited resources available, the Covenant imposes on article 13 general and specific legal obligations of immediate application, including ensuring that the right to education is exercised without discrimination and ensure universal access to primary education. Non-compliance with these obligations is a direct violation of the right to education. ${ }^{9}$ The Non-Discrimination Pact's provision requires a reduction of structural imbalances and sets the goal of effective participation and equality for all persons with disabilities. It recognizes that the best method of education is to integrate these people into the mainstream education system. In addition, the Covenant implicitly calls for States to integrate persons with disabilities into non-specialized education and continuing education. ${ }^{10}$

${ }^{8}$ L'article 24 de la Convention relative aux droits des personnes handicapées réaffirme le droit des personnes handicapées à l'éducation et reconnaît l'éducation inclusive comme le moyen de réaliser ce droit. La Convention constitue le premier instrument juridiquement contraignant qui fasse expressément référence à la notion d'éducation inclusive. À l'instar de la Convention sur l'élimination de toutes les formes de discrimination à l'égard des femmes et de la Convention relative aux droits de l'enfant, la Convention relative aux droits des personnes handicapées ne consacre pas un nouveau droit, mais précise les implications particulières pour les personnes handicapées de l'exercice du droit à l'éducation «sans discrimination et sur la base de l'égalité des chances».

9 See l'Observation générale ${ }^{\circ} 13$ du Comité des droits économiques, sociaux et culturels, par. 43 à 59, ainsi que son Observation générale $n^{\circ} 20$ (2009) sur la non-discrimination dans l'exercice des droits économiques, sociaux et culturels.

${ }^{10}$ Ibidem, Observation générale $n^{\circ} 5$ (1994) sur les personnes souffrant d'un handicap. D'autres traités internationaux relatifs aux droits de l'homme, dont la Convention sur l'élimi- 
The right to education is further recognized by regional human rights instruments, including the African Charter on Human and Peoples' Rights, the American Convention on Human Rights and its Additional Protocol dealing with economic, social and cultural rights, the Additional Protocol to the Convention for the Protection of Human Rights and Fundamental Freedoms and the Inter-American Convention on the Elimination of All Forms of Discrimination against People with Disabilities. The Committee on the Rights of the Child has advanced the realization of the right to inclusive education by calling as fundamental principles the maximum integration of children with disabilities in society (and the education system), and their right to education without discrimination and on the basis of equal opportunities. ${ }^{11}$ Discrimination undermines the ability of these children to benefit from educational opportunities and undermines the goal of developing their personality and developing their mental and physical gifts and abilities to the fullest. ${ }^{12}$ It is therefore necessary to provide support to ensure access to education in a manner conducive to achieving this goal. Resources allocated should be sufficient to cover all relevant needs, including funding programs to integrate children with disabilities into non-technical education. ${ }^{13}$ The Committee on the Rights of the Child has defined the concept of "inclusive education" as a set of values, principles and practices aimed at achieving a coherent, effective and quality education system, which takes into account the diversity of conditions and learning needs, not only of children with disabilities but also of all students. ${ }^{14}$ Article 24 , para. $2 \mathrm{~d}$. e, also requires States Parties to ensure that persons with disabilities receive the necessary support, including individualized support measures. ${ }^{15}$ The purpose of this provision is to ensure that people with communication disabilities are not excluded from the general education system and that they are taught in the

nation de toutes les formes de discrimination à l'égard des femmes, la Convention relative aux droits de l'enfant et la Convention internationale sur la protection des droits de tous les travailleurs migrants et des membres de leur famille, précisent les implications particulières pour des groupes donnés de l'exercice du droit à l'éducation. Ce droit est également reconnu par des instruments juridiques internationaux relevant du droit des réfugiés et du droit international humanitaire, ainsi que par plusieurs conventions de l'Organisation internationale du Travail ; Voir: l'Observation générale $n^{\circ} 1$ (2001) du Comité des droits de l'enfant sur les buts de l'éducation.

${ }^{11}$ Ibidem, Observation générale $n^{\circ} 9$ (2006) sur les droits des enfants handicapés, par. 11 et 62 .

${ }^{12}$ Ibidem, Observation générale $\mathrm{n}^{\circ} 1$, par. 10.

${ }^{13}$ Ibidem, Observation générale $n^{\circ}$ 9, par. 20.

${ }^{14}$ Ibidem, par. 67.

${ }^{15}$ Le paragraphe 3 de l'article 24 traite de l'égalité des chances des personnes handicapées et tout particulièrement des besoins des personnes atteintes d'un même type de handicap. 
appropriate languages or modes of communication, in environments that not only optimize their academic progress but also their socialization. ${ }^{16}$

In addition, educational staff and staff at all levels should have received training including disability awareness and the use of modes, means, and forms of communication as well as appropriate teaching techniques and materials. ${ }^{17}$ The Committee on the Rights of People with Disabilities, in concluding observations, called on States Parties to guarantee and implement the right to inclusive education. ${ }^{18}$ It encouraged the implementation of article 24 with a gender perspective. ${ }^{19}$ The Committee also recommended the integration of Roma ${ }^{20}$ children, people of African descent ${ }^{21}$ indigenous people and people living in rural areas $^{22}$ into non-specialized educational establishments. It indicated on several occasions preferring non-specialized institutions to specialized institutions. ${ }^{23}$

\section{Right of persons with disabilities to inclusive education: non-exclusion provision}

The right of people with disabilities to receive education in a non-specialized educational institution is enshrined in Article 24 (2) (a) of the Convention on the Rights of People with Disabilities, which states that no pupil may be excluded of the general education system on the basis of his disability. As a measure to combat discrimination, this "non-exclusion provision" is imme-

${ }^{16}$ Le paragraphe 4 de l'article 24 dispose que, pour que les systèmes d'enseignement général soient inclusifs, il faut employer des enseignants qui aient une qualification en langue des signes ou en braille.

${ }^{17}$ Le paragraphe 5 de l'article 24 porte sur l'accès à l'enseignement tertiaire général, à la formation professionnelle, à l'enseignement pour adultes et à la formation continue.

${ }^{18}$ See for example, the final observations on the rapports on Argentine, CRPD/C/ARG/ $\mathrm{CO} / 1$, et de $\mathrm{l}^{\prime}$ Espagne, CRPD/C/ESP/CO/1.

${ }_{19}$ See for exemple, la liste des points à traiter à l'occasion de l'examen des rapports initiaux de $1^{\prime}$ Autriche, CRPD/C/AUT/Q/1, de l'Argentine, CRPD/C/ARG/Q/1, de la Chine, CR$\mathrm{PD} / \mathrm{C} / \mathrm{CHN} / \mathrm{Q} / 1$, et du Pérou, CRPD/C/PER/Q/1.

${ }^{20}$ See the final observations the initial rapport on Hungary, CRPD/C/HUN/CO/1.

${ }^{21}$ See the final observations on the initial rapport on Pérou, CRPD/C/PER/CO/1.

22 See the final observations on the rapports on Argentine, CRPD/C/ARG/CO/1, et du Paraguay, CRPD/C/PRY/CO/1.

${ }_{23}$ See the final observations on the rapports on Paraguay, CRPD/C/PRY/CO/1 (passage d'un système d'enseignement spécialisé et séparé au modèle inclusif), de l'Argentine, CRPD/C/ $\mathrm{ARG} / \mathrm{CO} / 1$ (intégration des élèves handicapés scolarisés dans des établissements spécialisés dans des établissements non spécialisés), de la Chine, CRPD/C/CHN/CO/1 (prélèvement de ressources sur le budget du système d'enseignement spécialisé pour les affecter à l'intégration des élèves ayant des besoins particuliers dans le système scolaire ordinaire), et de l'Australie, CRPD/C/AUS/CO/1 (poursuite du placement des élèves handicapés dans des écoles spécialisées et placement fréquent de ceux qui sont scolarisés dans des écoles ordinaires dans des classes ou des unités spécialisées). 
diately applicable and is reinforced by the obligation to provide reasonable accommodation. It is recommended that education laws expressly include such a provision that prohibits refusal of admission to a non-specialized educational institution and ensures continuity in the educational pathway. It would be good to end disability-based assessments in the selection of the institution and to assess the need for support for effective integration into a non-specialized institution.

The legal framework relating to education should, as far as possible, impose any measure aimed at avoiding exclusion. Some education systems establish special mechanisms that exclude pupils, for example by setting an age limit for the completion of different grades. The legislative provisions that give effect to these systems and those that expressly exclude students from the education system on the basis of their disability should be changed. An inclusive education system is not synonymous with low-quality education. On the contrary, quality education is the cornerstone of the recommended measures. Linked to the notion of acceptability, it should, according to UNESCO's recommendations, include the following five dimensions: respect for rights, equity, usefulness, relevance, efficiency, and effectiveness. ${ }^{24}$ The fundamental right to education emphasizes the principles of free and compulsory primary education, as well as the gradual introduction of free secondary education and higher education accessible to all without discrimination. Non-discrimination can put an end to the exclusion and expulsion of the education system by encouraging participation in the decision-making process. Inclusive education calls for inclusive assessment methods. Cognitive learning is an indicator of quality education, but it is not the only one. Evaluation methods should be based on the proposed objectives of teaching, given the different dimensions that characterize quality teaching. ${ }^{25}$

In accordance with Article 9, ensuring accessibility is a primary obligation for States parties to the Convention on the Rights of Persons with Disabilities. These people frequently face barriers in terms of physical access and communication due to attitudes and socio-economic factors. This can have a negative impact on their access to the physical environment, knowledge, teaching materials and information. Fighting and eliminating these barriers is a prerequisite for inclusive education. Measures to remove barriers to physical access and communication have generally focused on modifying infrastructure and providing accessible means of transportation and communication tools, as well as promoting a universal design. States can provide financial assistance

\footnotetext{
${ }^{24}$ R. Blanca et al., Quality education for all: A human rights issue, UNESCO, Santiago 2007.

${ }^{25}$ See: G. McGregor, R. Timm Vogelsberg, Inclusive Schooling Practices: Pedagogical and Research Foundations. A Synthesis of the Literature that Informs Best Practice about Inclusive Schooling, Montana 1998.
} 
or incentives to students with disabilities to combat socio-economic barriers. It is important to note that universal access to free primary education implies that accessibility measures are equally accessible. Measures to raise public awareness under Article 8 of the Convention can help overcome such barriers. While implementation of accessibility measures is often the responsibility of local authorities, national standards need to be developed. ${ }^{26}$ Ensuring accessibility means taking the right steps to ensure that all students can truly access education. This obligation should also guide policy development in the field of education. If respected, it will gradually lead to more inclusive education systems. Some of these systems establish indicators to measure progress in implementing accessibility measures. These indicators should also include difficulties related to access to communication.

\section{Reasonable accommodation for inclusive education, training and capacity building}

Reasonable accommodation as defined in the Convention on the Rights of Persons with Disabilities is a measure to combat immediate discrimination. ${ }^{27}$ The purpose of this measure is to ensure that people with disabilities have access to education in the existing system on the basis of equality with others. The denial of reasonable accommodation constitutes a violation of the Convention. This type of evaluation standard has yet to be developed by the Committee on the Rights of Persons with Disabilities in its jurisprudence. The Committee on Economic, Social and Cultural Rights has issued guidelines on the obligation to take action for the implementation of the International Covenant on Economic, Social and Cultural Rights to the maximum of available resources, including the right to education. ${ }^{28}$ These guidelines on the "reasonableness" test may be relevant to the Convention on the Rights of Persons with Disabilities pending the Committee on the Rights of Persons with Disabilities's own guidelines for the development of specific standards for reasonable accommodation under the Convention. $t$ is further desirable that States enter

${ }^{26}$ See article 9, par. 2 a), de la Convention concernant l'élaboration et la promulgation de normes minimales et de directives relatives à l'accessibilité.

${ }^{27}$ See the final observations du Comité des droits des personnes handicapées concernant le rapport initial de l'Espagne, CRPD/C/ESP/CO/1, par. 44.

${ }^{28}$ Déclaration sur l'appréciation de l'obligation d'agir «au maximum de ses ressources disponibles» dans le contexte d'un protocole facultatif au Pacte, E/2008/22, annexe VIII, p. 146 et 147. Le Comité indique que le respect de cette obligation doit être évalué en fonction d'un certain nombre d'éléments tels que l'intention délibérée de réaliser les droits économiques, sociaux et culturels par les mesures adoptées, l'application d'une démarche non discriminatoire dans l'adoption de ces mesures et le délai. Les pénuries de ressources devraient être examinées par une analyse attentive du contexte. 
into interparliamentary cooperation with regard to legislative provisions and legal guidance for the direct application of the non-discrimination provision on reasonable accommodation. ${ }^{29}$

Teachers are key actors in building an inclusive education system. Article 24, paragraph 4 , stresses the need to train teachers to support students with disabilities and to promote quality education. In educational systems that promote integration, integration training programs, which also include inclusion, are already proposed ${ }^{30}$ On-the-job training is not only necessary to meet the needs of students in school but also to positively transform the system. ${ }^{31}$ Barriers to teaching need to be carefully addressed. Assistance should be provided to teachers to provide instruction to all students, including students with disabilities. Training in teaching techniques to teach students from different backgrounds and with different characteristics should be offered. Teachers should be able to reflect on their experiences and practices and thus review their methodology and the organization of their courses for better inclusion. Continuing learning is one element that guarantees the right to education. In paragraph 5 of article 24, States parties are requested to ensure that persons with disabilities have equal access to tertiary education and adult education on an equal basis with others. This provision is important because it highlights the need for higher education institutions to meet the educational needs of students with disabilities in a manner appropriate to their age. It highlights the principle that persons with disabilities cannot be limited in their progress with regard to their right to education on the grounds of a diagnosed medical disability. To reinforce this provision, the obligation to provide reasonable accommodation to ensure the right of persons with disabilities to education is reaffirmed in other articles of the Convention.

\section{National implementation and international cooperation in the field of inclusive education}

Inclusive education systems are the result of complex processes that need to be studied in a systemic way. The transformations at the level of the edu-

29 "Reasonable accommodation" under the convention means necessary and appropriate modification and adjustments, without imposing a disproportionate or undue burden in a particular case, to ensure to persons with disabilities the enjoyment or exercise of rights equally with others

${ }^{30}$ In Australia and Cuba, for example, training programs have been set up to facilitate access for students with disabilities to educational institutions. Inclusive education training, which is delivered prior to entry, is essential to prepare new teachers to teach to a diverse group of students and to use that diversity to teach and learn.

${ }^{31}$ In France and Colombia for example, teachers benefit from this training before taking up duties and being employed. 
cation system should include: on the one hand the adoption of an inclusive education law which includes a clear definition of the concept of inclusive education as well as a provision of "non-exclusion" setting out the principles of non-discrimination and reasonable accommodation; and on the other hand the establishment of a transformation plan to create the necessary conditions for effective inclusion. As a first step, obstacles to the legal and administrative levels need to be removed. The innovative nature of the human rights-based approach to disability and the inclusive approach to educational needs must be emphasized as practices that contribute to the development of inclusive education systems are adopted. The process of developing a law on inclusive education can be rewarding, especially when it is participatory. It is advisable to create partnerships between all stakeholders to design an inclusive education system and facilitate its implementation. To ensure the participation of those unfamiliar with the human rights-based approach to education, capacity-building programs should be put in place. For this, the centralization of education under the auspices of the Ministry of Education is useful. Centralization does not exclude local communities, which allow better participation of those directly affected, as provided for in Article 4, paragraph 3 of the Convention.

In order to achieve inclusion in the field of education, quantifiable objectives should be set in order to protect the human rights of people with disabilities and to establish appropriate data collection mechanisms. To measure progress, it is recommended to develop monitoring mechanisms that use structural indicators, ${ }^{32}$ method indicators, and outcome indicators, as well as specific benchmarks and objectives for each of these indicators, which should be used to measure barriers to inclusive education and not simply to collect data disaggregated by disability. ${ }^{33}$ Methodological indicators provide a better measure of the progress made in transforming education systems by identifying the number of teachers trained in inclusive teaching techniques, the number of accessible institutions and the number of students with disabilities who have transferred from a special educational institution to a regular educational institution. Outcome indicators should also be defined, including the percentage of students with disabilities in mainstream educational institutions who were enrolled in primary school and then obtained their certificate, and the percentage of students admitted to secondary education. The quality of education should also be assessed in the light of the different elements mentioned in paragraph 28 of the con-

${ }^{32}$ See the publication du Haut-Commissariat des Nations Unies aux droits de l'homme (HCDH) Indicateurs des droits de l'homme: Guide pour mesurer et mettre en ceuvre, New York Genève 2012.

${ }^{33}$ Par exemple, au Portugal, des indicateurs structurels de l'inclusion ont été définis. 
vention. It is also advisable to evaluate affirmative action measures, such as quotas or incentives. Remedies and remedies available for violation are important components of the implementation process at the national level. Relevant laws should provide for appropriate remedies or other appropriate complaints procedures. ${ }^{34}$ Providing remedies or reparations is a prerequisite for the effective implementation of article 13 of the Convention on the Rights of Persons with Disabilities, which concerns access to justice. States that are not yet parties to the Optional Protocol to the Convention should consider ratifying it to enable those who feel aggrieved to submit communications. The enforcement and monitoring mechanism provided for in Article 33 of the Convention is an indispensable tool for advancing the issue of inclusive education. National human rights institutions and mechanisms to monitor the implementation of the Convention have collected data on cases of refusal of admission of people with disabilities in mainstream education, carried out studies and surveys of persons with disabilities exclusions and obstacles, promoted quality education and recommended to carry out legislative and political reforms. ${ }^{35}$ Civil society groups, including organizations of persons with disabilities, have contributed effectively to creating momentum for inclusive education. ${ }^{36}$ The role of civil society is critical for the implementation of the provisions of the Convention, including international control, for example, reporting on the situation in China, ${ }^{37}$ promoting regulatory flexibility in Buenos Aires, ${ }^{38}$ contribution to policy development in the Lao People's Democratic Republic, ${ }^{39}$ campaigns for inclusion ${ }^{40}$ or teaching in sign language. In the Convention on the Rights of Persons with Dis-

${ }^{34}$ The laws of the Flemish Parliament concerning primary and secondary education provide for a mediation procedure in case of refusal of admission to an ordinary educational institution as well as the possibility of appealing if this mediation fails. Sanctions can be applied. Belgian anti-discrimination legislation provides for criminal sanctions for deliberate refusal to make reasonable accommodation, which is compulsory in the field of education.

35 See les communications des bureaux de l'Ombudsman à Buenos Aires, en Azerbaïdjan, dans l'État plurinational de Bolivie et en Colombie, de la Commission nationale des droits de l'homme au Rwanda, et de l'Ombudsman parlementaire en Finlande.

${ }^{36}$ Human Rights Watch, vidéo «Signs for Good Education» (Langue des signes pour une éducation de qualité) de 2013, disponible à l'adresse: http://deafnewstoday.blogspot.fr/2013/10/signs-for-good-education.html.

${ }^{37}$ Human Rights Watch, As long as they let us stay in class: Barriers to education for persons with disabilities in China (États-Unis d'Amérique, 2013).

${ }^{38}$ Le Groupe des 24 a obtenu l'adoption de réformes réglementaires à Buenos Aires, qui visent à aider les enfants handicapés scolarisés dans les écoles publiques et à assurer la continuité du cursus scolaire dans les écoles privées ordinaires.

${ }^{39}$ Contribution de l'association lao des personnes aveugles à la Stratégie nationale et au Plan d'action national pour l'éducation inclusive 2011-2015.

${ }^{40}$ Campagne «No excuses» menée par l'Association canadienne pour l'intégration communautaire en 2013. 
abilities, an entire article is devoted to the role of international cooperation (article 32) in the implementation of the rights of persons with disabilities. The contributions of States to this report offer a large number of examples in which international cooperation has facilitated the move towards inclusive education systems. Inclusive education is one of the areas of cooperation funded by the United Nations Partnership for the Promotion of the Rights of Persons with Disabilities.

\section{Conclusion}

Persons with disabilities face various forms of discrimination in schools. At school, the main barriers to the participation of students with disabilities are prejudices and misconceptions that lead to deliberate exclusion and segregation. Students with disabilities are stigmatized as it is considered that they cannot be trained in mainstream educational institutions, or even cannot be trained at all. This translates into educational systems in which persons with disabilities are deprived of the right to education as enshrined in Article 24 of the Convention on the Rights of Persons with Disabilities. The Convention provides for a two-phase implementation of the right to education for persons with disabilities: firstly, the application of a policy of non-discrimination in mainstream educational institutions and the strengthening of this right through reasonable accommodations; second, a system-wide change that requires progressive realization and a transformation plan to combat exclusion and segregation. The full implementation of this right is based on a complex evolutionary process that requires a transformation of the existing legislative and policy framework and a real commitment on the part of all stakeholders, in particular persons with disabilities and the organizations that represent them.

Through the adoption of inclusive education laws, states should establish an inclusive education system that they would place under the umbrella of their Ministry of Education and in which exclusion from an ordinary educational institution based on disability would be prohibited and reasonable accommodations mandatory. A transformation plan should set the framework for the implementation of an inclusive education system as well as quantifiable goals. States should set up training programs for teachers, allocate funds for making the necessary accommodations, provide materials for people with disabilities, promote inclusive environments, improve testing methods, promote the transfer of students with disabilities from specialized educational institutions to mainstream educational institutions, follow up on inclusive education indicators, provide appropriate support to 
students, and use appropriate communication channels and formats. Institutions must have adequate financial resources, but they should not be the ground for depriving a disabled person of the exercise of his or her right to education. The integration policy has given rise to many good practices that could serve as a starting point for the development of inclusive education systems. International cooperation has contributed to this process. Participants at the High-Level Meeting on Disability and Development decided that the establishment of inclusive education systems was a priority, which can contribute to further strengthening the process through the adoption, as part of post-2015 development, an inclusive education goal and the definition of expected results and appropriate indicators.

\section{BIBLIOGRAPHY}

Ainscow M., Understanding the development of inclusive schools, Falmer, London 1999.

Avrimidis E., Bayliss P., Burdon R., A survey into mainstream teachers' attitudes towards the inclusion of children with special educational needs in the ordinary school in one local education authority, Educational Psychology, 2000, 20(2).

Bernard A., Education for All and Children who are Excluded, 2000, Education for All 2000 Assessment. Thematic Studies. On the Internet: http://www2.unesco.org/wef/en-leadup/fi ndings_excluded\%20summary.shtm

Blanca R. et al., Quality education for all: A human rights issue, UNESCO, Santiago 2007.

Booth T., Ainscow M., The Index for Inclusion: Developing Learning and Participation in Schools, Centre for Studies on Inclusive Education, Bristol 2004.

Booth T., Who's reality counts? Putting the first last, Intermediate Technology Publications, London 1996.

Buckup S., The price of exclusion: The economic consequences of excluding people with disabilities from the world of work, Employment Working Paper, 2009, nº 43, OIT.

Chambers R., Who's reality counts? Putting the first last, Intermediate Technology Publications, London 1997.

Comité des droits économiques, sociaux et culturels, Observations générales no 11 (1999) sur les plans d'action pour l'éducation primaire et nº 13 (1999) sur le droit à l'éducation.

Dakar Framework for Action - Education for All, meeting our collective commitment. On Internet: http://www2.unesco.org/wef/enconf/dakframeng.shtm

Fine M., Creating Inclusive Communities. An Inquiry into organizational approaches for Pursuing Diversity, (2000)Academy for Education Development and The National Youth Leadership Council, Service-Learning Diversity project. On the Internet: http:/ / www. aed.org/publications/pubs_inclusion.pdf

$\mathrm{HCDH}$ sur le travail et l'emploi des personnes handicapées (A/HRC/22/25).

Les observations finales du Comité des droits des personnes handicapées concernant l'Argentine, CRPD/C/ARG/CO/1, et l'Espagne, CRPD/C/ESP/CO/1.

McGregor G., Timm Vogelsberg R., Inclusive Schooling Practices: Pedagogical and Research Foundations. A Synthesis of the Literature that Informs Best Practice about Inclusive Schooling, 
Consortium on Inclusive Schooling Practices, The University of Montana, Rural Institute on Disabilities, Montana 1998.

Meisfjord R., Mathisen, Womens's Views A qualitative case study of the impact of adult training on Women in South Africa, Oslo University College, Oslo 2001, Norway.

Observation générale $\mathrm{n}^{\mathrm{o}} 13$ du Comité des droits économiques, sociaux et culturels, par. 43 à 59, ainsi que son Observation générale $n^{\circ} 20$ (2009) sur la non-discrimination dans l'exercice des droits économiques, sociaux et culturels.

UNICEF, The Right of Children with Disabilities to Education: A Right-Based Approach to Inclusive Education, Genève, 2012. 